\title{
EVALUASI PLT BIOGAS TERANTAM COVERED LAGOON(CAL) 700 KW UNTUK PENGEMBANGAN PLT BIOGAS TIPE CSTR
}

\section{EVALUATION OF 700 KW COVERED LAGOON (CAL) TYPE TERANTAM BIOGAS POWER PLANT FOR DEVELOPMENT OF CSTR TYPE BIOGAS POWER PLANT}

\author{
Erlan Rosyadia), Nurdiah Rahmawatia), Astri Pertiwia), Galuh Wirama Murtia), Naafi Fauzan \\ M.S. ${ }^{\text {b), }}$ Tyas Puspita Rini ${ }^{\text {a) }}$, Bambang Muharto ${ }^{\text {a) }}$, Arya Bhaskara ${ }^{a}$, Hens Saputraa) \\ a)Badan Pengkajian dan Penerapan Teknologi \\ Gedung Energi 625, Puspiptek Serpong, Tangerang Selatan \\ b)Teknik Bioenergi dan Kemurgi FTI ITB \\ e-mail : erlan.rosyadi@bppt.go.id
}

\begin{abstract}
Abstrak
Produksi Crude Palm Oil (CPO) di Indonesia semakin meningkat setiap tahunnya dan diprediksi mencapai 42,9 juta ton per tahun pada akhir tahun 2019. Setiap ton CPO yang diproduksi akan menghasilkan 2,5 ton POME yang tidak hanya dapat mencemari tanah dan perairan, namun juga akan melepas gas metan ke atmosfer dan menimbulkan emisi gas rumah kaca, jika tidak ditangani dengan tepat. BPPT bekerja sama dengan PTPN V memanfaatkan POME untuk menghasilkan biogas yang selanjutnya dikonversi menjadi listrik dalam suatu Pembangkit Listrik Tenaga Biogas ( $P L T B g$ ) di Terantam dengan kapasitas desain $700 \mathrm{~kW}$. Reaktor yang digunakan adalah jenis Covered Anaerobik Lagoon (CAL) yang dilengkapi dengan pompa resirkulasi. Hasil evaluasi menunjukkan bahwa teknologi yang dipilih memberikan hasil yang belum optimal selama pengoperasian, ditunjukkan oleh adanya akumulasi cake dan endapan sludge di dalam reaktor yang dapat mengganggu berlangsungnya reaksi anaerobik. Pengembangan teknologi dilakukan melalui pembangunan PLTBg Sei Pagar yang menggunakan teknologi CSTR. Pada kapasitas reaktor yang sama, CSTR memiliki HRT yang lebih singkat dibandingkan dengan CAL sehingga kebutuhan lahannya lebih sedikit. CSTR juga lebih mudah disesuaikan $\mathrm{pH}$ dan temperaturnya.
\end{abstract}

Kata Kunci : POME; Biogas; CSTR; Covered Lagoon; HRT; OLR

\begin{abstract}
Production of Crude Palm Oil (CPO) in Indonesia increases every year and predicted to reach 42,9 million tonnes per year by the end of 2019. Each tonne of CPO produced will generate 2,5 tonnes of POME, that will cause not only soil and water pollution, but also release methane gas to the atmosphere and induce greenhouse gas emission if not treated properly. BPPT in collaboration with PTPN V utilize POME to produce biogas and then converted into electricity in a Biogas Power Plant (PLTBg) in Terantam with a design capacity of $700 \mathrm{~kW}$. The reactor used is a Covered Anaerobic Lagoon (CAL) type equipped with a recirculation pump. The evaluation results indicate that the chosen technology has not delivered the optimal result yet during the operation, evidenced by the accumulation of cakes and sludge inside the reactor which could disturb the anaerobic reaction. The technology development carried out through the Sei Pagar PLTBg project which uses CSTR technology. At the same reactor capacity, the CSTR has a shorter HRT compared to CAL which leads to less land requirement. CSTR is also easier in term of $\mathrm{pH}$ and temperature control.
\end{abstract}

Keyword : POME; Biogas; CSTR; Covered Lagoon; HRT, OLR

Diterima (received ) : 20 November 2019, Direvisi (revised ) : 16 Desember 2019,

Disetujui (accepted) : 23 Desember 2019 


\section{PENDAHULUAN}

Produksi Minyak Sawit Mentah (CPO) di Indonesia semakin meningkat setiap tahunnya dan diprediksi mencapai 42,9 juta ton per tahun pada akhir tahun 20191). Hal ini akan berdampak pada peningkatan volume limbah yang dihasilkan dari proses produksinya. Salah satunya adalah limbah cair yang biasa disebut Palm Oil Mill Effluent (POME). Setiap ton CPO yang diproduksi akan menghasilkan 2,5 ton $\mathrm{POME}^{2)}$, yang artinya Indonesia berpotensi menghasilkan POME hingga 107 juta ton pada akhir tahun 2019. Tanpa penanganan yang tepat, POME dapat menimbulkan pencemaran tanah dan perairan karena sifat fisika-kimianya. POME akan mengganggu ekosistem akuatik, mengubah air menjadi kecoklatan, berbau dan menyebabkan terjadinya oxygen depletion karena tingginya kandungan organik di dalamnya ${ }^{3,4}$. Pelepasan gas seperti $\mathrm{CO}_{2}, \mathrm{CH}_{4}$, dan $\mathrm{H}_{2} \mathrm{~S}$ oleh POME juga akan menyebabkan efek pemanasan global jangka panjang, masalah pernapasan pada manusia dan hewan, dan kerusakan lingkungan akibat hujan asam. Metan diketahui menimbulkan efek gas rumah kaca 21 kali lipat dibandingkan dengan karbon dioksida ${ }^{5,6)}$.

Pembangkit Listrik Tenaga Biogas (PLTBg) Terantam merupakan PLTBg yang mampu mengkonversi biogas yang berasal dari Palm Oil Mill Effluent (POME) menjadi energi listrik. PLTBg ini merupakan proyek kerja sama BPPT dengan PTPN V Riau dan berlokasi di Pabrik Kelapa Sawit (PKS) Terantam. PLTBg Terantam memiliki kapasitas desain sebesar $700 \mathrm{~kW}$. PLTBg Terantam terbagi ke dalam lima sub-sistem yaitu sub-sistem pre-treatment POME, subsistem reaksi anaerobik, sub-sistem gas handling (pembersihan gas), sub-sistem pembangkitan listrik, dan sub-sistem pengolahan akhir effluent (post treatment), yang seluruhnya terintegrasi satu sama lain.

Salah satu parameter penting dalam evaluasi proses di PLTBg Terantam adalah komposisi biogas yang masuk ke dalam gas engine. Kandungan pengotor yang tinggi di dalam biogas akan menyebabkan penurunan kinerja konversi energi di dalam gas engine sehingga menurunkan efisiensi proses. Selain itu, pengotor dapat menyebabkan korosi pada komponen-komponen gas engine maupun unit lainnya. Hal ini akan menyebabkan tingginya biaya untuk perawatan peralatan. Setiap biogas engine memiliki kebutuhan spesifik dalam hal komposisi biogas yang dapat diterima. Pada PLTBg Terantam, kriteria ideal komposisi biogas yang harus dicapai adalah kadar $\mathrm{H}_{2} \mathrm{~S}$ kurang dari 200 ppm, dan kadar $\mathrm{CH}_{4}$ lebih besar dari $50 \%$ volume ${ }^{7 \text { ). }}$.

Tujuan dari tulisan ini adalah memberikan hasil evaluasi kinerja proses melalui pengamatan terhadap parameter rancangan desain proses pada tiap subsistem dalam PLTBg Terantam dan memberikan gagasan peningkatan kinerja proses yang telah berlangsung berdasarkan kriteria proses yang telah ditentukan.

\section{DESKRIPSI MASALAH}

PLTBg Terantam saat ini belum dapat dioperasikan secara kontinyu karena jaringan atau beban listrik yang akan dipasok masih dalam proses pembangunan. Meski demikian, PLTBg Terantam secara rutin menjalankan prosedur pemeliharaan untuk mempertahankan kondisi unit-unit prosesnya sehingga saat beban jaringan listrik selesai dibangun, PLTBg dapat langsung dioperasikan secara kontinyu. Prosedur pemeliharaan meliputi proses feeding dan flaring, serta perawatan unit-unit secara mekanikal tanpa tanpa mengoperasikan gas engine.

Proses feeding dan flaring merupakan dua proses yang penting dalam prosedur pemeliharaan suatu plant biogas dari sudut pandang proses kimia. Proses feeding bertujuan untuk mempertahankan kondisi digester dengan cara memberikan substrat, dalam hal ini POME, untuk dicerna oleh mikroorganisme yang ada di dalam digester. Dengan demikian, ekosistem mikrorganisme dalam digester akan terus terpelihara. Hal ini sangat penting karena jika mikroorganisme di dalam digester mati, proses start up digester akan memerlukan biaya dan waktu yang banyak. Ekosistem mikroorganisme yang terpelihara dengan baik di dalam digester akan menghasilkan biogas. Biogas yang dihasilkan belum dapat dikonversi menjadi listrik karena beban jaringan yang belum tersedia. Di sisi lain, biogas akan menyebabkan efek rumah kaca yang signifikan jika langsung dilepas ke atmosfer. Oleh karena itu, untuk menurunkan tekanan di dalam covered lagoon, secara rutin dilakukan flaring, yaitu membakar biogas menjadi gas buang yang lebih ramah lingkungan.

Proses feeding dan flaring melibatkan hampir seluruh sub-sistem dalam PLTBg Terantam, kecuali sub-sistem pembangkitan listrik. Sub-sistem yang terlibat adalah subsistem pre-treatment, sub-sistem reaksi anaerobik, sub-sistem gas handling, dan sub-sistem post treatment. Proses evaluasi 
Evaluasi PLT Biogas Terantam Covered Lagoon (CAL) 700 kW Untuk Pengembangan PLT Biogas Tipe CSTR (Erlan Rosyadi, Nurdiah Rahmawati, Astri Pertiwi, Galuh Wirama Murti, Naafi Fauzan M.S., Tyas Puspita Rini, Bambang Muharto, Arya Bhaskara, Hens Saputra)

dilakukan pada semua sub-sistem yang terlibat. Dengan demikian, potensi permasalahan yang akan timbul ketika PLTBg Terantam dioperasikan secara kontinyu sesuai kapasitas desain, akan dapat segera diidentifikasi dan selanjutnya dicarikan alternatif solusi pemecahannya.

\section{Sub-sistem Pre-treatment}

Parameter yang diperhatikan mencakup temperatur dan kadar padatan pada cooling pond, temperatur dan $\mathrm{pH}$ pada mixing pond, dan hal teknis lain yaitu pembentukan cake.

a. Cooling pond belum beroperasi, sehingga umpan masuk ke mixing pond adalah POME segar dengan temperatur yang masih tinggi dan $\mathrm{pH}$ yang masih rendah (asam).

b. Pada mixing pond, teramati bahwa pengadukan antara POME segar dengan effluent digester masih belum sempurna. Selain itu, diduga temperatur dan $\mathrm{pH}$ umpan masuk ke dalam reaktor masih belum sesuai kondisi optimal reaktor.

\section{Sub-sistem Reaktor Anaerobik}

Parameter yang diperhatikan mencakup komposisi biogas, temperatur, dan laju alir.

a. Pompa resirkulasi belum dioperasikan sehingga diduga di dalam reaktor terdapat akumulasi cake dan endapan sludge yang dapat mengganggu proses reaksi anaerobik.

b. Tekanan biogas di dalam reaktor tidak dapat diketahui.

\section{Sub-sistem Gas Handling}

Parameter yang diperhatikan pada bioscrubber adalah komposisi $\mathrm{H}_{2} \mathrm{~S}$, sedangkan pada heat exchanger adalah temperatur masuk dan temperatur keluar

Tabel 1 berikut. a. Heat exchanger belum bisa menurunkan temperatur biogas menjadi sesuai parameter desain yaitu $12^{\circ} \mathrm{C}$.

b. Bio-scrubber dapat menurunkan kadar $\mathrm{H}_{2} \mathrm{~S}$ secara signifikan dalam waktu yang singkat.

\section{Sub-sistem Pengolahan Effluent Akhir}

Pengamatan kondisi pada sub-sistem ini dilakukan secara kualitatif.

a. $\mathrm{pH}$ dan komposisi effluent di Final Effluent Pond belum diketahui datanya.

b. Bio-scrubber berpotensi dijadikan pupuk bersama dengan abu boiler dari PKS.

Penanganan akumulasi cake atau sludge padat masih belum efektif.

\section{BAHAN DAN METODE}

\section{Metode Pengumpulan Data}

Pengumpulan data dilakukan melalui observasi lapangan mencakup data kuantitatif dari alat ukur yang tersedia di lapangan dan data kualitatif dari pengamatan visual. Data yang diperoleh dianalisis untuk mendapatkan hubungan antar data dan kesimpulan berdasarkan pada perbandingan dengan data dalam Basic Engineering Design Data (BEDD) PLTBg Terantam milik BPPT sebagai acuan spesifikasi yang seharusnya.

Sistem yang diobservasi mencakup 4 (empat) sub-sistem yaitu sub-sistem pretreatment, sub-sistem reaktor anaerobik, sub-sistem gas handling dan sub-sistem post treatment. Parameter-parameter yang diobservasi dan diukur untuk setiap sistem ditampilkan dalam

Tabel 1.

Sistem yang Diobservasi dan Parameter yang Diukur

Sistem yang Dievaluasi

Sistem Pre-treatment

Sistem Reaktor Anaerobik

\section{Parameter yang diukur}

- $\mathrm{pH}$ dan temperatur pada sistem cooling pond, sistem mixing pond, umpan masuk, serta treated POME keluaran dari reaktor anaerobik.

- Kadar padatan di dalam POME segar.

- Komposisi biogas, laju alir gas, dan temperatur biogas keluaran dari reaktor 
H2S dalam biogas dengan unit bio-scrubber

2) Unit Heat exchanger dan Chiller

Sistem Post Treatment
- Temperatur gas masuk dan keluar Heat exchanger

- observasi terhadap bagaimana kondisi dan mekanisme kinerja unit

\section{Langkah Kerja}

\section{Pengukuran pH}

Pengukuran $\mathrm{pH}$ dilakukan pada aliran cairan (aliran POME, effluent, dan campuran) menggunakan $\mathrm{pH}$ meter merek Hana. Berikut langkah kerja dalam pengukuran $\mathrm{pH}$.

a. Sampel diambil pada titik sampling menggunakan wadah/gelas kimia.

b. Cairan diaduk hingga homogen.

c. $\mathrm{pH}$ meter dicelupkan ke dalam sampel hingga menunjukan angka yang stabil.

d. Sampel yang telah selesai diukur kemudian dimasukan kembali ke dalam aliran (kolam) agar tidak dibuang di sembarang tempat.

e. Prosedur dilakukan secara duplo, dan data $\mathrm{pH}$ yang dicatat adalah rata-rata dari dua data yang diperoleh.

\section{Pengukuran Temperatur}

Pengukuran temperatur cairan (aliran POME, effluent, dan campuran) dilakukan dengan melihat pada termometer pada pipa aliran atau dilihat pada panel mimic diaram yang ada di dalam ruang kontrol secara langsung. Selain itu, pengukuran temperatur cairan dilakukan dengan bersamaan dengan pengukuran $\mathrm{pH}$ karena $\mathrm{pH}$ meter yang digunakan dapat mengukur $\mathrm{pH}$ dan temperatur secara simultan.

\section{Pengukuran Laju Alir Cairan dan Gas}

Pengukuran laju alir cairan dilakukan dengan melihat nilai yang terukur pada flowmeter aliran POME dari cooling pond ke mixing pond. Pengukuran laju alir gas dilakukan dengan melihat nilai yang terukur pada flowmeter aliran biogas sebelum bio-scrubber. Nilai terukur yang stabil dicatat langsung, dan nilai terukur yang tidak stabil dicatat berupa rentang nilai minimum dan maksimum sebagai data.

\section{Pengukuran Komposisi Biogas}

Pengukuran komposisi biogas dilakukan dengan melihat nilai terukur pada Gas Analyzer yang terletak setelah blower biogas sebelum dialirkan ke dalam tangki biogas.

\section{Penentuan Pengaruh Rasio Effluent : POME Segar Terhadap pH Campuran}

Percobaan ini dilakukan untuk mengetahui rasio yang tepat dalam pencampuran POME segar dengan effluent dari digester di dalam mixing pond sebagai proses pretreatment kondisi parameter $\mathrm{pH}$. Berikut langkah percobaan yang dilakukan.

a. Sampel POME segar dan effluent diambil dari titik sampling menggunakan suatu wadah yang terpisah.

b. Gelas kimia dan gelas ukur disiapkan.

c. $10 \mathrm{ml}$ POME segar diambil dari wadah dengan gelas ukur dan dimasukkan ke dalam gelas kimia

d. Sampel POME segar diaduk dan diukur $\mathrm{pH}$-nya.

e. Effluent dicampurkan ke dalam sampel POME dalam gelas kimia dengan

f. Variasi rasio volume Effluent : POME sebesar 1:1, 2:1, 3:1 dan 4:1.

g. Setiap penambahan effluent, campuran diaduk dan diukur $\mathrm{pH}$-nya.

h. Data $\mathrm{pH}$ yang diperoleh dari rasio tersebut dicatat.

\section{Alat dan Bahan}

Alat dan bahan yang digunakan disajikan dalam

Tabel 2 berikut.

Tabel 2.

Alat dan Bahan

Alat Bahan

- Oven

- pH meter HANA

- Flow meter cairan

- Flow meter gas

- Gas analyzer

- Gelas ukur $100 \mathrm{ml}$

- Gelas kimia 100 ml

- Cawan pengeringan

- Batang pengaduk

- Spatula 
Evaluasi PLT Biogas Terantam Covered Lagoon (CAL) 700 kW Untuk Pengembangan PLT Biogas Tipe CSTR (Erlan Rosyadi, Nurdiah Rahmawati, Astri Pertiwi, Galuh Wirama Murti, Naafi Fauzan M.S., Tyas Puspita Rini, Bambang Muharto, Arya Bhaskara, Hens Saputra)

\section{HASIL DAN PEMBAHASAN}

\section{Evaluasi Sistem PLTBg Terantam}

\section{Evaluasi Sistem Pre-treatment}

Evaluasi pada sistem pre-treatment dilakukan melalui observasi lapangan dan pengukuran nilai $\mathrm{pH}$ dan temperatur pada arus POME segar dan arus inlet dan outlet pada cooling pond maupun mixing pond. Data hasil pengukuran temperatur dan nilai $\mathrm{pH}$ pada sistem pre-treatment, dibandingkan dengan nilai desain sesuai BEDD PLTBg Terantam, ditampilkan dalam Tabel 3 berikut.

Tabel 3.

Data hasil pengukuran temperatur dan nilai $\mathrm{pH}$ pada sistem pre-treatment, dibandingkan dengan nilai desain sesuai BEDD PLTBg Terantam ${ }^{8)}$

\begin{tabular}{|c|c|c|c|c|c|c|c|c|}
\hline \multirow[t]{2}{*}{ Parameter } & \multirow{2}{*}{$\begin{array}{c}\text { Flowrate } \\
\text { POME ke } \\
\text { mixing } \\
\text { pond } \\
\left(\mathrm{m}^{3} / \mathrm{jam}\right)\end{array}$} & \multicolumn{4}{|c|}{ Temperatur $\left({ }^{\circ} \mathrm{C}\right)$} & \multicolumn{3}{|c|}{$\mathrm{pH}$} \\
\hline & & $\begin{array}{c}\text { POME } \\
\text { dari } \\
\text { PKS }\end{array}$ & $\begin{array}{l}\text { POME } \\
\text { inlet } \\
\text { mixing } \\
\text { pond }\end{array}$ & $\begin{array}{l}\text { Effluent } \\
\text { inlet } \\
\text { mixing } \\
\text { pond }\end{array}$ & $\begin{array}{l}\text { Outlet } \\
\text { mixing } \\
\text { pond ke } \\
\text { digester }\end{array}$ & $\begin{array}{l}\text { POME } \\
\text { inlet } \\
\text { mixing } \\
\text { pond }\end{array}$ & $\begin{array}{c}\text { Effluen } \\
t \text { inlet } \\
\text { mixing } \\
\text { pond }\end{array}$ & $\begin{array}{c}\text { Outlet } \\
\text { mixing } \\
\text { pond ke } \\
\text { digester }\end{array}$ \\
\hline $\begin{array}{l}\text { Di lapangan } \\
\text { tanpa } \\
\text { Cooling Pond } \\
\text { dan screen }\end{array}$ & $19,5-22,5$ & $48-58$ & $48-58$ & $33-34,4$ & $49,9-50,7$ & $\begin{array}{c}4,63- \\
4,67\end{array}$ & $\begin{array}{l}7,12- \\
7,49\end{array}$ & 6,24 \\
\hline $\begin{array}{l}\text { Di lapangan } \\
\text { dengan } \\
\text { Cooling Pond } \\
\text { dan screen }\end{array}$ & 18 & $65,2-66,7$ & $40-50$ & 33,4 & $36,4-44,7$ & $4,2-4,51$ & $\begin{array}{l}7,25- \\
7,32\end{array}$ & $4,62-4,96$ \\
\hline $\begin{array}{l}\text { Spesifikasi } \\
\text { Desain }\end{array}$ & 20 & 50 & 20-40 & $20-40$ & $20-40$ & $4-5$ & $7-8$ & $7-8$ \\
\hline
\end{tabular}

\section{Evaluasi Cooling Pond}

Saat observasi, didapati bahwa pada permukaan cooling pond tidak terdapat akumulasi cake. Hal ini mengindikasikan tidak adanya aktivitas biologi, disebabkan oleh temperatur umpan POME segar yang masih tinggi. Dari pengukuran temperatur, didapatkan bahwa cooling pond mampu menurunkan temperatur POME segar hingga mencapai $40-50^{\circ} \mathrm{C}$. Sedangkan nilai pH dalam cooling pond masih sama dengan kondisi POME segar, berkisar antara 4-5.
Pemasangan screen dilakukan pada pipa POME segar inlet ke dalam cooling pond dengan diameter lubang screen $\pm 0,5 \mathrm{~cm}$. Dalam rentang waktu antara 30-60 menit, di dalam screen telah terakumulasi padatan yang cukup banyak. Tingginya kandungan padatan dalam POME segar ini dapat menyebabkan masalah pada sistem pompa dan risiko akumulasi endapan padatan yang tak tercerna oleh mikroorganisme di dalam reaktor anaerobik.

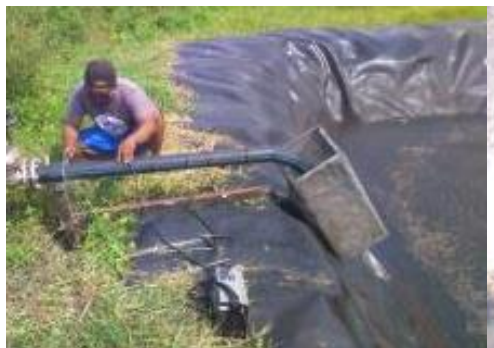

(a)

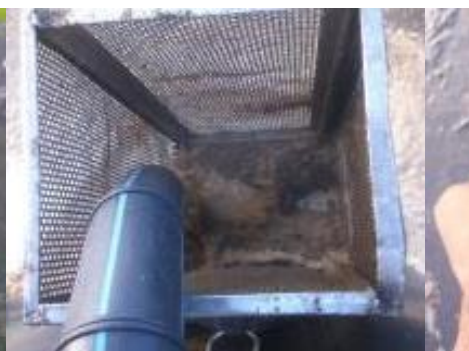

(b)

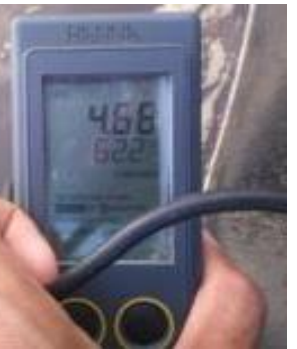

(c)

Gambar 1.

Pemasangan screen pada unit mixing pond (a), padatan yang tersaring dalam screen (b), dan pengukuran $\mathrm{pH}$ dan temperatur (c)

\section{Evaluasi Mixing Pond}

Saat observasi, didapati adanya akumulasi cake pada permukaan mixing pond.
Hal ini mengindikasikan adanya aktivitas biologi di dalam mixing pond, yaitu aktivitas aerobik, yang menghasilkan produk samping berupa cake. Akumulasi cake pada 
permukaan mixing pond juga mengindikasikan belum sempurnanya proses pengadukan dalam mixing pond. Hal ini diperkuat dengan data temperatur arus keluaran mixing pond masuk ke dalam reaktor yang belum sesuai dengan desain yaitu sebesar $\pm 50^{\circ} \mathrm{C}$ (tanpa cooling pond) dan antara $36-44^{\circ} \mathrm{C}$ (dengan cooling pond), sedangkan dalam desain diinginkan temperatur arus masuk ke dalam reaktor antara $20-40^{\circ} \mathrm{C}$. Selain temperatur, nilai $\mathrm{pH}$ arus keluaran mixing pond juga belum sesuai dengan desain yaitu sebesar 6,24 (tanpa cooling pond) dan 4,62-4,96 (dengan cooling pond) sedangkan dalam desain diinginkan antara 7-8. Lebih lanjut, keberadaan akumulasi cake pada mixing pond dapat menggangu proses pengadukan, menyumbat aliran dalam pipa dan merusak pompa.

Nilai $\mathrm{pH}$ merupakan salah satu parameter penting dalam umpan masuk ke dalam reaktor. Mikroorganisme dalam digester akan berekasi terhadap perubahan $\mathrm{pH}$ baik karena faktor eksternal (misalnya dari umpan digester) maupun faktor internal (karena berbagai intermediate yang terbentuk selama reaksi anaerobik). Bakteri anaerobik umumnya akan beraktivitas dengan baik pada kisaran $\mathrm{pH} 6,5-7,5$, dan paling optimal pada $6,8-$ $7,6^{9,10)}$. Oleh karena itu, penyesuaian kondisi $\mathrm{pH}$ pada umpan digester menjadi sangat penting, yang di antaranya dapat dilakukan melalui pencampuran POME segar dengan effluent dari digester di dalam mixing pond. Selain observasi lapangan, juga dilakukan percobaan laboratorium untuk mengetahui pengaruh rasio pencampuran POME segar dengan effluent dari reaktor terhadap nilai $\mathrm{pH}$ arus keluaran mixing pond. Dalam percobaan dilakukan pencampuran $10 \mathrm{ml}$ POME segar $(\mathrm{pH}=4,72)$ dengan berbagai variasi rasio effluent ( $\mathrm{pH}=7,47)$. Hasil percobaan ditampilkan dalam Gambar 2 berikut.

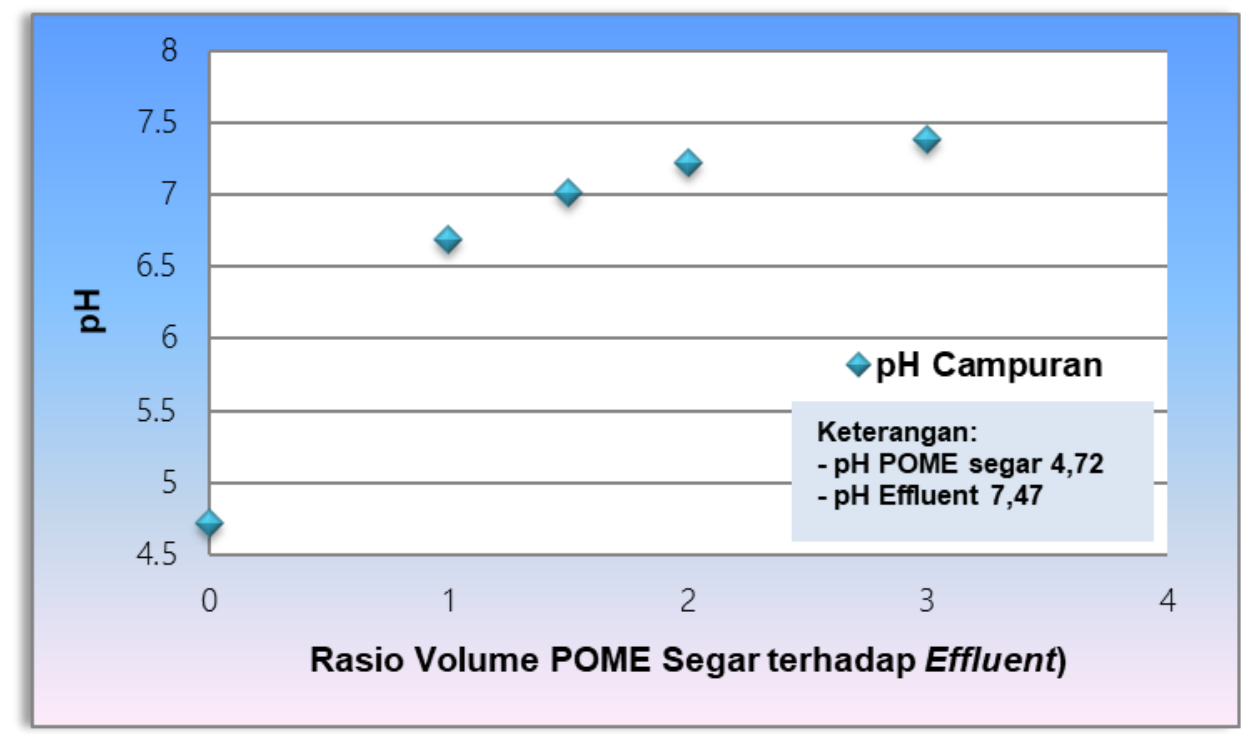

Gambar 2.

Pengaruh rasio pencampuran effluent dan POME segar terhadap $\mathrm{pH}$ arus keluaran dari mixing pond

Berdasarkan hasil percobaan skala laboratorium di atas, dengan asumsi bahwa pengadukan berlangsung sempurna di dalam mixing pond, diperlukan rasio volume POME segar terhadap effluent sebesar 1,5 : 1 untuk dapat menaikkan $\mathrm{pH}$ campuran menjadi netral $(\mathrm{pH}$ 7) sebagaimana kebutuhan desain reaktor anaerobik.

Pengadukan memegang peran penting dalam mixing pond, untuk itu perlu dilakukan upaya untuk meningkatkan efisiensi pengadukan sehingga dapat berlangsung sempurna. Hal ini dapat dilakukan di antaranya dengan mengubah posisi inlet POME segar maupun effluent dari reaktor sehingga sirkulasi di dalam mixing pond dapat berlangsung lebih baik. Inlet POME dan inlet effluent sebaiknya diposisikan bersebelahan dan jauh dari pipa penghisap (feeding pump). Posisi yang bersebelahan akan memungkinkan terjadinya pencampuran dengan segera ketika kedua arus inlet tersebut mengalir masuk ke dalam mixing pond. Sebagai alternatif lain, dapat dilakukan penambahan unit pompa dalam mixing pond, namun opsi ini akan memerlukan daya listrik yang tinggi.

\section{Evaluasi Sistem Reaktor Anaerobik Covered Lagoon}


Evaluasi pada sistem reaktor anaerobik Covered Lagoon dilakukan melalui observasi lapangan dan pengukuran nilai temperatur dan $\mathrm{pH}$ pada arus inlet dan outlet reaktor. Dalam BEDD PLTBg Terantam, reaktor didesain untuk beroperasi pada kondisi mesofilik dengan temperatur antara 20 $40^{\circ} \mathrm{C}$ dan nilai $\mathrm{pH}$ antara 7-8. Selain itu, juga dilakukan pengukuran temperatur dan komposisi biogas keluar digester $\left({ }^{\circ} \mathrm{C}\right)$. Berdasarkan data spesifikasi dari penyedia gas engine Jenbacher yang terpasang di PLTBg Terantam, konsentrasi $\mathrm{CH}_{4}$ dalam biogas harus berada dalam rentang antara $50-60 \%$ dan kandungan $\mathrm{H}_{2} \mathrm{~S}$ dalam biogas harus di bawah $200 \mathrm{ppm}$. Data hasil pengukuran temperatur dan komposisi biogas serta parameter effluent ditampilkan dalam

Tabel 4 berikut.

Tabel 4.

Data hasil pengukuran temperatur dan komposisi biogas serta parameter effluent ${ }^{8)}$

\begin{tabular}{lccccccc}
\hline \multirow{2}{*}{ Hari Tanggal } & Temperatur & \multicolumn{3}{c}{ Komposisi Biogas } & \multicolumn{2}{c}{ Effluent } \\
\cline { 6 - 8 } & biogas keluar & $\mathrm{CH}_{4}(\%)$ & $\mathrm{CO}_{2}(\%)$ & $\begin{array}{c}\mathrm{H}_{2} \mathrm{~S} \\
(\mathrm{ppm})\end{array}$ & Temperatur & $\mathrm{pH}$ \\
\hline Minggu, 07 Juli & 37 & 56,6 & 32,5 & 1.541 & - & 7,12 \\
Senin, 08 Juli & 38 & 57,5 & 32,4 & 1.606 & - & 7,54 \\
Selasa, 09 Juli & 40 & 57,6 & 32,3 & 1.620 & 34,4 & $7,3-7,49$ \\
Kamis, 11 Juli & 38 & 56,9 & 31,4 & 1.595 & 33 & 7,35 \\
Minggu, 14 Juli & $37-40$ & 57,2 & 31,5 & 1.509 & - & - \\
Spesifikasi desain & $\mathbf{2 0 - 4 0}$ & $50-60$ & - & $<\mathbf{2 0 0}$ & $\mathbf{2 0 - 4 0}$ & $7-8$ \\
\hline
\end{tabular}

Dari data dalam tabel di atas, didapatkan bahwa temperatur dan $\mathrm{pH}$ effluent berada dalam rentang spesifikasi desain. Konsentrasi $\mathrm{CH}_{4}$ dalam biogas sebesar $50-60 \%$ juga sesuai dengan spesifikasi gas engine. Namun, konsentrasi $\mathrm{H}_{2} \mathrm{~S}$ di dalam biogas jauh melebihi syarat yang ditetapkan, yaitu antara 1.500$1.600 \mathrm{ppm}$. Untuk menurunkan konsentrasi $\mathrm{H}_{2} \mathrm{~S}$, telah dipasang suatu unit bio-scrubber. Unit bio-scrubber ini mampu bekerja pada konsentrasi $\mathrm{H}_{2} \mathrm{~S}$ hingga 3.500 ppm ${ }^{11}$.

Reaktor anaerobik Covered Lagoon pada kondisi tunak, dirancang untuk mengolah POME segar dengan laju alir $20 \mathrm{~m}^{3} / \mathrm{jam}$ selama 20 jam pengumpanan per hari. Kadar COD dalam POME segar sebesar 45.000 ppm. Sedangkan volume reaktor anaerobik adalah $12.000 \mathrm{~m}^{3}$. POME segar diumpankan ke dalam reaktor setelah dicampur dengan effluent dari reaktor dengan rasio POME segar terhadap effluent sebesar $1: 2$.

Parameter operasi yang penting dalam reaktor anaerobik adalah HRT dan OLR, yang dihitung menggunakan persamaan sebagai berikut.

$H R T=\frac{\text { Volume Reaktor }\left(m^{\mathrm{a}}\right)}{\text { Laju Alir Umpan }\left(m^{\mathrm{a}} / \text { hari }\right)}$

$O L R=C O D_{i} \times \frac{1}{H R T}$
Dari hasil perhitungan diperoleh nilai HRT reaktor sebesar 30 hari, dan nilai OLR sebesar $1,5 \mathrm{~kg} . \mathrm{COD} / \mathrm{m}^{3} /$ hari. Pada tahap persiapan dimana durasi feeding sebesar 3 jam/hari, diperoleh nilai OLR yang lebih kecil yaitu sebesar $0,225 \quad \mathrm{~kg} . \mathrm{COD} / \mathrm{m}^{3} / \mathrm{hari}$, yang berdampak pada volume biogas yang lebih rendah dari nilai desain.

Reaktor Covered Lagoon umumnya memiliki nilai HRT sebesar 40 hari dan OLR sebesar $1,4 \mathrm{~kg} . \mathrm{COD} / \mathrm{m}^{3} / \mathrm{hari}{ }^{12)}$. Hal ini disebabkan karena sistem reaktor CAL yang ada di PLTBg Terantam memiliki sistem sirkulasi pada mixing pond sehingga memiliki nilai HRT yang lebih kecil dan OLR yang lebih besar. Untuk penelitian lebih lanjut, perlu dilakukan pengkajian pengaruh rasio pada pencampuran dalam mixing pond terhadap perolehan biogas yang didapatkan. Akibat nilai OLR dan HRT di atas, sistem PLTBg Terantam belum dapat berjalan optimal sesuai desain. Adapun solusi pengembangan teknologi digester selanjutnya akan dilakukan dengan pembangunan PLTBg Sei Pagar dengan menggunakan teknologi CSTR. Kelebihan dengan teknologi CSTR yang berkapasitas digester sama adalah HRT lebih cepat karena OLR lebih tinggi dengan penyesuaian $\mathrm{pH}$ dan Temperatur. 


\section{Evaluasi Sistem Gas Handling}

Evaluasi pada sistem gas handling dilakukan melalui observasi lapangan pada bio-scrubber dan dehumidifier, serta pengukuran laju alir dan komposisi biogas.

Bio-scrubber memanfaatkan mikroorganisme Thiobacillus Sp. yang dapat hidup pada rentang $\mathrm{pH} 1-3$. Mikroorganisme tersebut menempel sebagai biofilm di permukaan packing yang menjadi isian bioscrubber. Proses yang terjadi dalam bioscrubber adalah reaksi aerobik yang

Tabel 5 berikut. mengonversi $\mathrm{H}_{2} \mathrm{~S}$ menjadi $\mathrm{SO}_{4}$ dan padatan Sulfur yang akan dibuang menjadi komposisi limbah PLTBg Terantam.

\section{Evaluasi Bio-scrubber}

Kinerja bio-scrubber dapat diketahui dari perbandingan data komposisi biogas ketika dilewatkan melalui Bio-scrubber dan ketika dialirkan bypass tanpa melewati Bioscrubber. Data laju alir dan komposisi biogas setelah melewati bioscrubber dan ketika dialirkan bypass ditampilkan dalam

Tabel 5.

Data laju alir dan komposisi biogas setelah melewati bioscrubber dan ketika dialirkan bypass

\begin{tabular}{|c|c|c|c|c|c|}
\hline \multirow{2}{*}{ Biogas } & \multicolumn{4}{|c|}{ Komposisi } & \multirow{2}{*}{$\begin{array}{c}\text { Laju alir biogas } \\
\left(\mathrm{m}^{3} / \mathrm{jam}\right)\end{array}$} \\
\hline & $\mathrm{CH}_{4}(\%)$ & $\mathrm{CO}_{2}(\%)$ & $\mathrm{H}_{2} \mathrm{~S}$ (ppm) & $\mathrm{O}_{2}(\%)$ & \\
\hline $\begin{array}{l}\text { ByPass } \\
\text { Melalui Bio-scrubber }\end{array}$ & $\begin{array}{l}56,6-57,7 \\
50-55\end{array}$ & $\begin{array}{c}31,4-32,5 \\
30-34\end{array}$ & $\begin{array}{c}1.509-1.620 \\
9-130\end{array}$ & $\begin{array}{c}0 \\
1,1-1,8\end{array}$ & $106-150$ \\
\hline
\end{tabular}

Dari tabel di atas, dapat dilihat bahwa komposisi biogas mengalami perbedaan yang signifikan setelah dilewatkan ke unit Bioscrubber, yaitu konsentrasi $\mathrm{H}_{2} \mathrm{~S}$ yang turun dari 1.509-1.620 ppm menjadi 9-130 ppm untuk laju alir biogas antara 106-150 $\mathrm{m}^{3} / \mathrm{jam}$. Biogas sudah memenuhi syarat untuk diumpankan ke dalam gas engine.

\section{Evaluasi Unit Dehumidifier}

Unit utama pada sistem unit dehumidifier terdiri atas unit heat exchanger dan unit chiller. Parameter yang diperhatikan pada evaluasi unit ini adalah temperatur gas masuk dan temperatur gas keluar. Berdasarkan pengamatan yang telah dilakukan, temperatur masuk biogas ke dalam heat exchanger adalah pada rentang $46,6-53^{\circ} \mathrm{C}$ dan temperatur keluar berkisar pada suhu 20$25^{\circ} \mathrm{C}$.Suhu yang diamati di lapangan tersebut tidak sesuai dengan spesifikasi desain yang terdapat di BEDD. Berdasarkan spesifikasi desain, temperatur masuk biogas adalah sebesar $35^{\circ} \mathrm{C}$ dan temperatur keluar biogas adalah sebesar $12^{\circ} \mathrm{C}$.

Diduga, temperatur masuk yang berada di atas spesifikasi desain tersebut yaitu pada $46,6-53^{\circ} \mathrm{C}$ disebabkan oleh reaksi yang ada di dalam Bio-scrubber sehingga temperatur biogas keluaran digester yang berada pada temperatur mesofilik akan meningkat akibat kondisi di dalam Bio-scrubber tersebut.

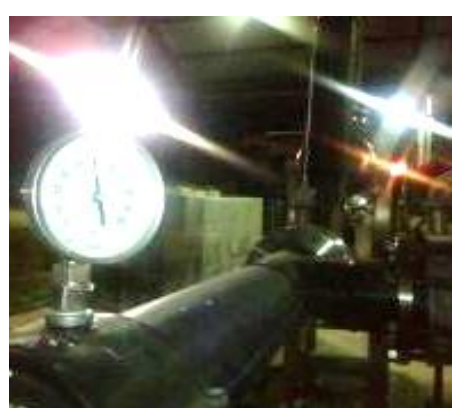

Gambar 3.

Temperatur biogas sebelum unit Dehumidifier sebesar $48^{\circ} \mathrm{C}$

Unit dehumidifier jarang dioperasikan pada saat operasi flaring dilakukan, hal ini bertujuan untuk menghemat listrik yang disuplai dari PKS Terantam. Oleh karena itu, pengamatan pada unit dehumidifier terbatas. Untuk itu, dilakukan simulasi menggunakan software Aspen untuk mengevaluasi unit heat exchanger.

\section{Evaluasi Sistem Post-Treatment}

Unit utama dalam sistem post-treatment adalah final effluent pond, yang berisi effluent dari digester dengan $\mathrm{pH}$ netral cenderung basa. Dari hasil observasi di lapangan, terdapat akumulasi cake pada permukaan final effluent pond dengan ketebalan $\pm 20 \mathrm{~cm}$ sebagaimana ditampilkan dalam

Gambar 4 berikut. 


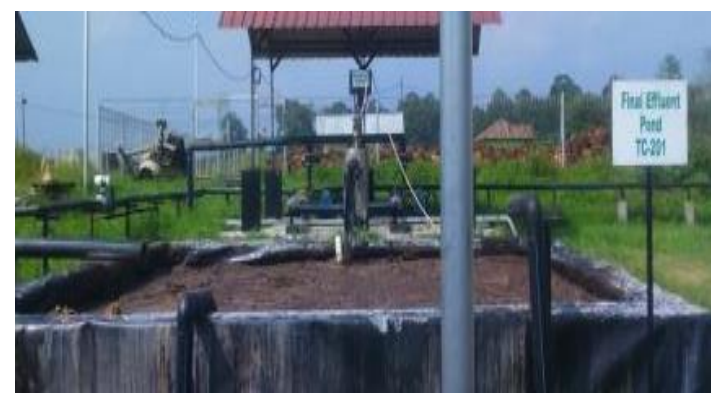

Gambar 4.

Akumulasi cake pada permukaan final effluent pond

Cake pada permukaan final effluent pond tersebut akan terikut ke dalam kolam Instalasi Pengolahan Air Limbah (IPAL) dan diolah mengikuti alur yang telah ada. Keluaran IPAL dengan kadar COD yang telah sesuai standar dapat dikembalikan ke kebun sawit dalam bentuk pupuk cair maupun pupuk padat.
Cake padatan memerlukan mekanisme pengeluaran yang tertentu, dalam hal ini dilakukan modifikasi desain kolam, baik dalam mixing pond, final effluent pond, maupun cooling pond, dengan konsep sebagai berikut. Cake yang mengambang di level cairan tengah kolam harus diangkat ke permukaan kolam, menggunakan mekanisme overflow cairan oleh inlet overflow effluent dari digester. Selanjutnya cake yang telah berada di permukaan kolam kemudian didorong atau ditarik secara manual oleh operator untuk dikeluarkan dari kolam melalui pintu/jalur di sisi dinding kolam yang telah dimodifikasi. Cake yang telah keluar dari pond dapat dipindahkan untuk pengolahan/ pemanfaatan lebih lanjut.

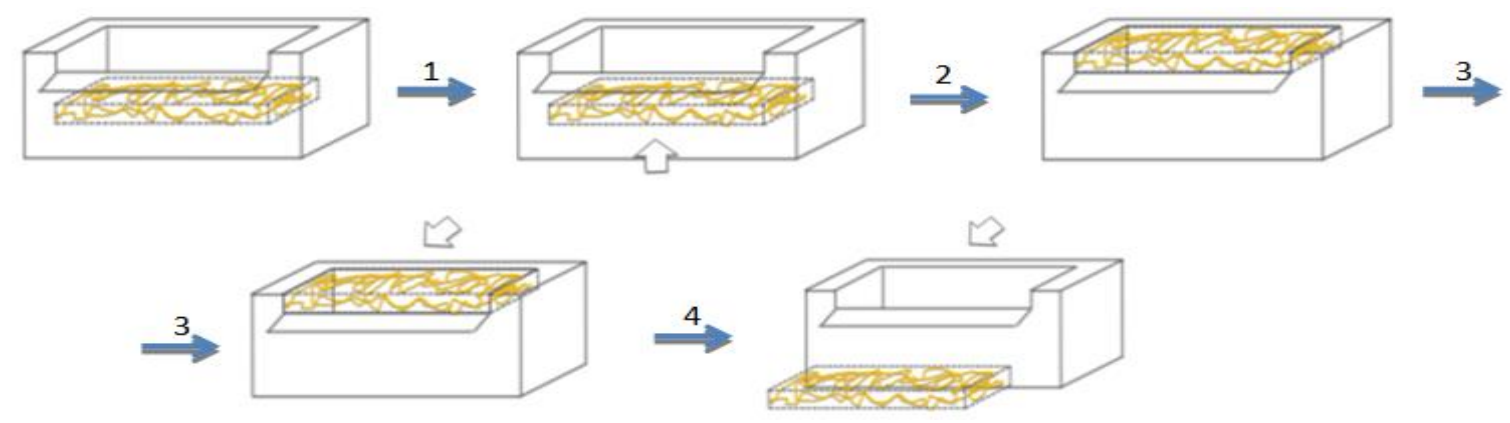

Gambar 5.

Ilustrasi mekanisme pengeluaran padatan sludge/cake dari unit kolam

Selain diolah dalam IPAL, cake juga berpotensi untuk pemanfaatan lain, di antaranya sebagai pupuk/kompos dengan proses fermentasi, yang selanjutnya dapat digunakan pada kebun kelapa sawit. Menurut Ansori dkk. 2018, pengolahan POME menjadi biogas dipadukan dengan sistem produksi kompos dari limbah cair dan tandan kosong kelapa sawit merupakan cara yang lebih menguntungkan. Selain itu, cake juga dapat diumpankan kembali ke digester. Sebelum diumpankan, cake harus di-treatment terlebih dahulu agar dapat terlarut dalam cairan POME. Treatment yang dilakukan dapat menggunakan enzim untuk memecah cake sehingga menjadi substrat yang lebih sederhana dan dapat larut sehingga mudah untuk dialirkan serta tidak menyebabkan penyumbatan pada pompa.

\section{Evaluasi Keseluruhan PLTBg Terantam}

Pada tahap persiapan, dimana beban jaringan masih dalam tahap pemasangan, PLTBg Terantam belum dioperasikan secara penuh. Biogas yang dihasilkan belum dikonversi menjadi listrik, melainkan dilepas ke lingkungan melalui prosedur flaring. Pada tahap ini, pengumpanan POME ke dalam digester dilakukan selama 1,5-3 jam per hari, lebih rendah dari nilai desain yaitu 20 jam per hari. Hal ini akan berdampak pada rendahnya nilai OLR, yang selanjutnya akan mempengaruhi volume biogas yang dihasilkan. Biogas yang dihasilkan dalam tahap persiapan adalah sebesar 106-150 $\mathrm{m}^{3}$ /jam dengan frekuensi blower antara 10-15 $\mathrm{Hz}$, lebih kecil dari spesifikasi laju alir desain sebesar $442,93 \mathrm{~m}^{3} / \mathrm{jam}$ pada tekanan kurang dari 50 mbarg dan temperatur $35^{\circ} \mathrm{C}$.

Peningkatan laju alir biogas akan terjadi ketika PLTBg Terantam dioperasikan dalam kapasitas penuh. Peningkatan laju alir ini akan 
berdampak pada tingkat penghilangan $\mathrm{H}_{2} \mathrm{~S}$ dari dalam biogas yang terjadi dalam unit bioscrubber, dan tingkat penurunan temperatur biogas dalam unit penukar panas.

\section{Evaluasi Teknologi Reaktor Anaerobik Selain CAL}

Reaktor CAL dipilih dalam PLTBg Terantam karena sistemnya sederhana, stabil, handal dan relatif murah. Harsono et al. 2014 menyatakan bahwa sebanyak $50 \%$ dari pabrik kelapa sawit menggunakan kolam anaerobik untuk mengolah POME yang dihasilkan, dan sisanya menggunakan teknologi jenis lain $^{13)}$. Kolam anaerobik yang telah ada di dalam Pabrik Kelapa Sawit dapat dimodifikasi menjadi reaktor CAL dengan biaya yang diharapkan lebih sedikit dibandingkan jika membangun suatu jenis teknologi baru. Dibandingkan teknologi lain, kebutuhan energi dan biaya operasional pada reaktor CAL juga lebih rendah, demikian pula kebutuhan nutriennya. Reaktor ini juga dapat menoleransi nilai OLR yang tinggi (hingga 1,4 $\mathrm{kg} \cdot \mathrm{COD} / \mathrm{m}^{3} /$ hari) sehingga dapat dengan mudah menangani POME selama puncak musim panen. Meski demikian, reaktor CAL memerlukan lahan yang luas. Ukuran dan strukturnya yang besar menyebabkan sulitnya proses kontrol dan monitoring. Meskipun jumlah sludge yang dihasilkan relatif sedikit, namun sludge akan terakumulasi dalam reaktor dan sulit dikeluarkan. Kelemahan utama dari reaktor $\mathrm{CAL}$ adalah tingginya nilai HRT yang diperlukan (lebih dari 40 hari), sehingga kurang efisien, meskipun tingkat penghilangan COD bisa mencapai hingga $97,8 \%$. Yield biogas per COD yang dihilangkan belum dapat diketahui, namun komposisi $\mathrm{CH}_{4} / \mathrm{H}_{2}$ dalam biogas bisa mencapai $54,4 \%{ }^{12}$.

Berbagai jenis teknologi lain dapat dipilih selain reaktor CAL, di antaranya adalah Anaerobic filtration, anaerobic fluidized bed reactor, Upflow anaerobic sludge blanket (UASB), Expanded granular sludge bed reactor (EGSB), Anaerobic baffled reactor $(A B R)$, Anaerobic sequencing batch reactor (ASBR), Continuous stirred tank reactor (CSTR), dan Upflow anaerobic sludge fixed film (UASFF).

Di antara berbagai teknologi tersebut, UASFF merupakan teknologi yang menunjukkan performa terbaik untuk produksi biogas dari POME karena mampu menangani OLR yang tinggi dengan HRT yang singkat ${ }^{14)}$. Meski demikian, CSTR memiliki kesiapan teknologi yang lebih baik untuk diaplikasikan di lapangan dengan skala besar, karena konstruksi dan pengoperasian yang lebih sederhana, dibandingkan dengan CAL, CSTR memiliki HRT yang lebih cepat sehingga membutuhkan lebih sedikit lahan.

\section{SIMPULAN}

Adapun saran yang dapat disampaikan adalah, Pengolahan kelapa sawit dengan prinsip 'zero waste' ditujukan ke arah pemanfaatan limbah padat, cair dan gas dari Pabrik Kelapa Sawit semaksimal, seefisien, dan seefektif mungkin, melalui pengembangan teknologi CSTR yang mampu memperpendek HTR menjadi 10 hari dibandingkan HTR pada teknologi CAL yang mencapai 30 hari.

Perbaikan teknis dalam sistem PLTBg Terantam diusulkan mencakup perbaikan sistem pengadukan dalam mixing pond, yang dapat dilakukan melalui pengaturan ulang posisi inlet POME segar maupun outlet dari reaktor sehingga resirkulasi berjalan lebih optimal, atau melalui pemasangan pompa di dalam mixing pond.

Mengembalikan unsur hara yang terkandung dalam limbah padat dan cair, dari proses pengolahan POME maupun CPO, kembali ke kebun kelapa sawit. Agar terciptanya industri kelapa sawit yang berkelanjutan.

Perlu dilakukan kajian untuk mengkonfirmasi hasil penelitian skala laboratorium mengenai pengaruh rasio pencampuran POME segar:Effluent di dalam mixing pond terhadap perolehan biogas, dengan melakukannya pada kondisi kontinyu. Hal ini bertujuan untuk mengetahui kondisi umpan POME yang bervariasi dalam menghasilkan biogas yang paling optimal di dalam digester.

\section{UCAPAN TERIMAKASIH}

Penulis mengucapkan terimakasih kepada manejemen PTSEIK atas bantuannya dan kepada seluruh staf PTSEIK yang telah banyak membantu, juga kepada Kemenristekdikti melalu insinas Flagship Program yang telah membantu pendanaan.

\section{DAFTAR PUSTAKA}

1. Direktorat Jenderal Perkebunan. Statistik Perkebunan Indonesia 2017-2019: Kelapa Sawit. Kementerian Pertanian Republik Indonesia, 2018.

2. Rahayu, A. S., dkk., Buku Panduan Konversi POME Menjadi Biogas 
Pengembangan Proyek di Indonesia, Winrock International, 100, 2015. Retrieved from https://www.winrock.org/ wp-content/uploads/2016/05/CIRCLEHandbook-INDO-compressed.pdf

3. Ohimain, E.I., Seiyaboh, E.I., Izah, S.C., Oghenegueke, V.E., Perewarebo, T.G., Some selected physico-chemical and heavy metal properties of palm oil effluents. Greener Journal Physical Science, 2(4), 131 - 137, 2012.

4. Awotoye, O.O., Dada, A.C., Arowomo, G.A.O., Impact of palm oil processing effluent discharging on the quality of receiving soil and rivers in South Western Nigeria. Journal of Applied Science Resources, 7(2), 111 - 118, 2011.

5. Ohimain, E.I., Izah, S.C., Possible contributions of palm oil mill effluents to green house gas emissions in Nigeria. Journal Apllied Science Technolgy, 4(33), 4705 - 4720, 2014.

6. Igoni, A.H., Abowei, M.F.N., Ayotamuno, I.O., Adeoti, O., Effect of total solids concentration of municipal solid waste in an anaerobic batch digestion on the biogas produced, Journal Food, Agriculture and Environmental, 5(2), 333 337, 2007.

7. Technical Specification, Jenbacher Gas engines, JMS 320 GS-B.L, Jenbach, Austria.
8. Badan Pengkajian dan Penerapan Teknologi, Basic Engineering Desain Data PLTBg Terantam, Tangerang Selatan, 2018.

9. Nayono, S.E., Anaerobic Digestion of organic wastes for energy, Scientific Publishing, ISBN 978-3-86644-464-5, p. 720, 2010.

10. Stronach, S.M., Rudd, T., Lester, J.N., Anaerobic digestion processes in waste water, Berlin, Springer, 1986.

11. Bioclean. Manual book bio-scrubber.

12. Ahmed, Y., Yaakob, Z., Akhtar, P., \& Sopian, K., Production of biogas and performance evaluation of existing treatment processes in palm oil mill effluent (POME), Renewable and Sustainable Energy Reviews, 42, 12601278, 2015.

https://doi.org/10.1016/j.rser.2014.10.073

13. Harsono, S.S., Grundmann, P., Soebronto, S., Anaerobic treatment of palm oil effluents potential contribution to net energy yield and reduction of greenhouse gas emission from biodiesel production, Journal of Cleaner Production, 64, 619-627, 2014.

14. Poh, P.E., Chong, M.F., Development of anaerobic digestion methods for palm oil mill effleuent (POME) treatment, Bioresources Technology, 100, $1-9$, 2009. 
(halaman ini sengaja dikosongkan) 